\title{
苦情発生の有無からみた実在住宅床振動の測定条件，境界值の提示 \\ THE MEASUREMENT METHOD OF ACTUAL HOUSE FLOOR VIBRATION AND THE CRITERION TO PREVENT COMPLAINT FROM OCCUPANTS
}

\author{
横山 裕*1 \\ Yutaka YOKOYAMA
}

\begin{abstract}
This paper proposes the practical measurement method of floor vibration and the criterion to prevent the complaint from occupants. Using twenty actual wooden and light weight steel-frame floors, the vibration excited by human walking and previously developed "Excitation and Perception Apparatus" is measured. The applicability of the apparatus for actual houses is confirmed by comparing the vibration measurements. The relationship between the vibration measured by the apparatus and the data on the complaint is investigated by using sixty-eight actual floors. The proposed measurement method and the criterion enable to utilize the previously proposed evaluation method of floor vibration.
\end{abstract}

keywords : Floor Vibration, Actual House, Complaint, Walking, Measurement Method, Criterion 床振動, 実在住宅, 苦情, 歩行, 測定条件, 境界値

1.はじめに

建築物内の人間の動作により発生する床振動は、居住性の観点から 重要な性能のひとつである。近年、床の軽量化，低剛性化などが原因 で、歩行など日常的で軽微な加振力でも床に有感振動が発生し、苦情 などにつながる事例が多数報告されている。

居住性からみた床振動の評価方法を提示するためには、実状に即し かつ安定性の高い床振動の測定方法の確立と、測定した床振動を評価 するための定量的な評価指標の提示が必要である。小野と筆者らは、 これらの枠組みに沿った床振動の評価方法を提示している1) 7)。すな わち、実験室に設置した試料床を用い、試料床の振動と官能検查手法 を適用して定量化した検査員の評価との関保から、床振動の評価指標 を提示している。また、床振動の測定方法を確立する目的で、実状に 即した加振，受振条件で床振動を測定できる床振動测定装置を開発 し、面積 $910 \times 910 \mathrm{~mm}$ の試料床を用いて妥当性を検証している。ただ し、これらの研究で提示した評価方法を実在建築物床の評価により広 く活用するためには、以下の課題の解決が望ましい状況にある。 (1)面的広がりを有する実在建築物床に対する床振動測定装置の適用性 の確認

(2)実際の日常生活の中での居住者の評価と床振動の関係の把握 (3)実在建築物休を評価する場合の実用的な適用方法の提示

本報は、様々な木造，軽量鉄骨造実在住宅床を対象に、歩行と装置 による床振動を測定，比較し、さらに居住者からの苦情発生の有無と 床振動との関係を検討した経過，結果を述べるものである。
なお本報は、日本建築学会大会での発表8)に、さらに検討を加えた ものである。

\section{2. 本研究の目的, 範囲}

本研究は、床振動測定装置の実在建築物床に対する適用性を確認す るとともに、実際の日常生活の中での居住者の評価の例として苦情発 生の有無をとりあげ、苦情発生の有無と床振動の関係を把握し、さら に苦情発生の有無の観点から実在建築物床を評価する場合の実用的な 床振動の測定条件，境界值を提示することを目的とする。

本研究で対象とする床は、設計段階での振動の予測などが困難で、 かつ日本建築学会の「建築物の振動に関する居住性能評価指針・同解

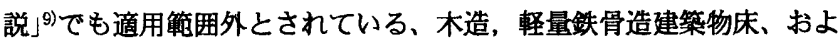
びRC造スラブ上などに施工された木造，軽量鉄骨造二重床(以降あわ せて“木造，軽量鉄骨造床”之記す)とする。また対象とする床用途 は、木造，軽量鉄骨造床で主要でかつ苦情発生事例が多い住宅の居室 とする。ここで、住宅で発生する苦情の多くは、最も日常的でかつ避 けられない動作である歩行による床振動を、同一室内にいる歩行者以 外の居住者(以降単に“居住者”と記す)が近傍で感じる場合に発生して いることから、本研究では歩行による床振動を近傍の居住者が感じる 場合を対象とすることとする。さらに対象とする履物は、住宅内で一 般的でかつ加振力が最も大きい)、素足と近似した装着感を有するく つ下とする。

本報は、実在住宅床を媒体として、歩行と床振動測定装置による床

*1 東京工業大学大学院理工学研究科建築学専攻 助教授. 工博 Assoc. Prof., Dept. of Architecture and Building Eng., Graduate School of Science and Eng., Tokyo Institute of Technology, Dr. Eng. 
振動を比較するとともに、苦情発生の有無と床振動の関係を検討する ものであり、床の具体的な仕様と苦情発生の有無との関係の検討や、 床振動の観点からよりよい床仕様の究明などは、議論の範囲外とする。

\section{3. 既往の研究}

実在建築物における人間の動作時の床振動と苦倩などとの関俰に関 する研究例としては、苦情発生の有無と床振動の振幅, 振動数の関係 を統計的に検討し判別式を提示した櫛田の研究 ${ }^{10)}$ が挙げられる。ま たこの他にも、個々の苦情発生事例に関する報告がある程度みられ る。しかし、これらはいずれもRC造スラブなどを対象としたもので あり、木造，軽量鉄骨造床を対象とした例はみあたらない。

一方、人間の動作時の床振動を再現できる装置を開発し、実在建築 物床で適用性を確認した研究例はみあたらない。

\section{4. 床振動の評価方法の概要}

\section{1 歩行時に発生する床振動の概要}

図ー 1 に、筆者らが測定した人間が歩行時に床に与える荷重の時間 変化(荷重・時間曲線)および歩行時に発生する床振動(変形・時間曲 線，加速度・時間曲線)の例5),6) を、吉岡らが測定した足の接地状況と の関係例 ${ }^{11}$ とともに示す。図に示した床振動の例は、周团から縁の切 れた床(図一2参照)に1歩着地して歩き抜けた場合のものである。

歩行時に発生する床振動は、一般に、かかとの先端が着地した時点 の荷重のピーク $p_{1}$ により励起される床の固有振動数での減衰振動(加 速度・時間曲線参照)と、足裏全体が着地した時点の荷重のピーク $p_{2}$ やけり出し時のピーク $p_{3}$ などに相応した動的変形(変形・時間曲線参 照)が複合された、複雑な性状を示す1),9\%。

\section{2 床振動の評価指標の概要}

筆者と小野は、歩行時に発生する床振動の感覚上の大きさは、下式 で表される物理量VI(2)(Vibration Index 2)で表示できることを明ら かにしている3)。

$V I(2)=0.2 \cdot \log (D \max )+0.5 \cdot \log (V m)+\log (T h)$

ここでDmax $(\mathrm{cm}):$ 最大変形量(図一1参照)

$V m(\mathrm{~cm} / \mathrm{s}): D \max T \mathrm{~m}$ (図ー1参照)で除した変形速度

$T h(\mathrm{~s})$ : 床の固有振動数での減衰振動の振幅が14.1Galまで 減衰するのに要する振動隇衰時間(図一 1参照)

さらに筆者と小野は、VI(2)と官能検查手法を適用して構成した床 振動の評価に関する心理学的尺度(床振動評価尺度)の関係を、床振動 の評価指標として提示している4)。图ー3に提示した評価指標の例を示 す。図中の(1) (7)の点線は、官能検查に用いた判断範ちゅうの床振動 評価尺度上の位置を表すものである。

\section{3 床振動の測定方法の概要}

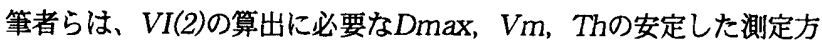
法を確立する目的で、図一4に示す床振動測定装置を開発している5,6)。 床振動測定装置は、動的加振器, 衝撃的加振器, 受振器の3種の装置 からなる。

動的加振器は、図ー1に示したピーク $p_{2}$ などと同等の加振力を床に

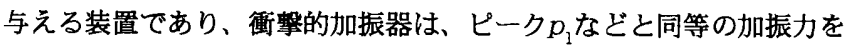
床に与える装置である。ここで、ピーク $p_{1}$ は動作の形態などの影響で 大きくばらつくため、衝撃的加振器の仕様は、図一4の(2)に示す通 り、加振力の分布の中心近傍を再現できる“中心仕様”之、最大近傍を
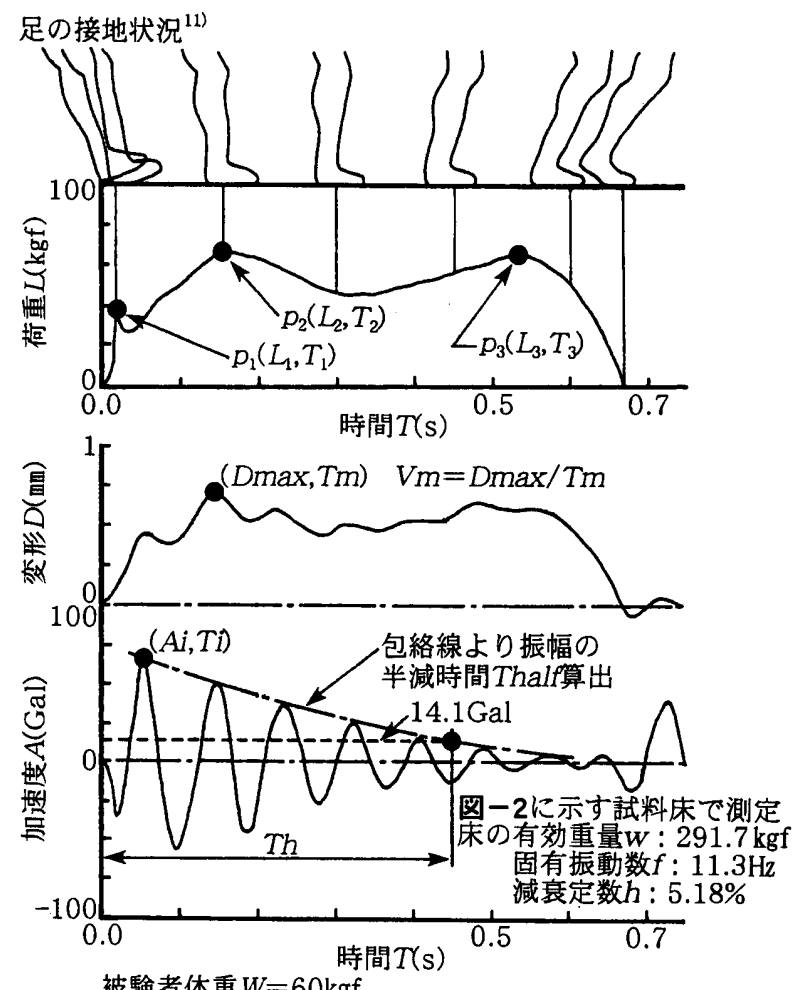

被験者体重 $W=60 \mathrm{kgf}$

$(W=75.4 \mathrm{kgf}$ 被験者による測定結果より換算)

\section{図-1 歩行時の荷重および床振動の例 ${ }^{5), 6)}$}

再現できる“最大仕様”の2種が設定されている。一方受振器は、歩行 者や居住者の人体と近似した振動特性を有する1自由度振動系を床に 付加する装置である。

床振動測定装置の妥当性は、図一 2 に示す面積 $910 \times 910 \mathrm{~mm}$ の試料床を 用いて歩行と装置による床振動を测定, 比較することにより検証されて いる。すなわち、動的加振器で歩行時のDmax, Vmを、衝撃的加振器 でAi, TIを、また受振器で振幅の半堿時間Thalf(図一1参照)を再現でき ることが、確認されている。

\section{4 床振動の評価方法の概要}

4.2，4.3をまとめて、歩行時に発生する床振動の評価方法を、以下 の通り提示した。

1)床上の居住者が載っている位置(以降“居住点”と記す)に、居住者の 人体の代替となる受振器を付加する。

2)1)の状態で、床上の歩行者が着地する位置(以降“着地点”と記す)を 動的加振器で加振し、D max,Vmを測定する。

3)1)の状態で、着地点を衝撃的加振器で加振し、Ai，Tiを測定する。 4)1)に加え、着地点に歩行者の人体の代替となる受振器を付加し、八 ンマーなどで床を打撃してThalfを測定する。

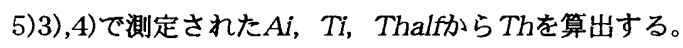

6)2),5)で測定，算出されたDmax，Vm，ThからVI(2)を算出し、評 価指標(図一3)と照合して評価する。

以上であるが、実在住宅床を評価する場合には、着地点, 居住点お よびVI(2)を測定，算出する点(以降“測定点”と記す)と、3)で用いる衝 撃的加振器の仕様を、適宜設定する必要がある。本研究ではこれらを 床振動の測定条件として提示するとともに、この条件で測定されるVI(2) を用いて境界値を提示することとする。 

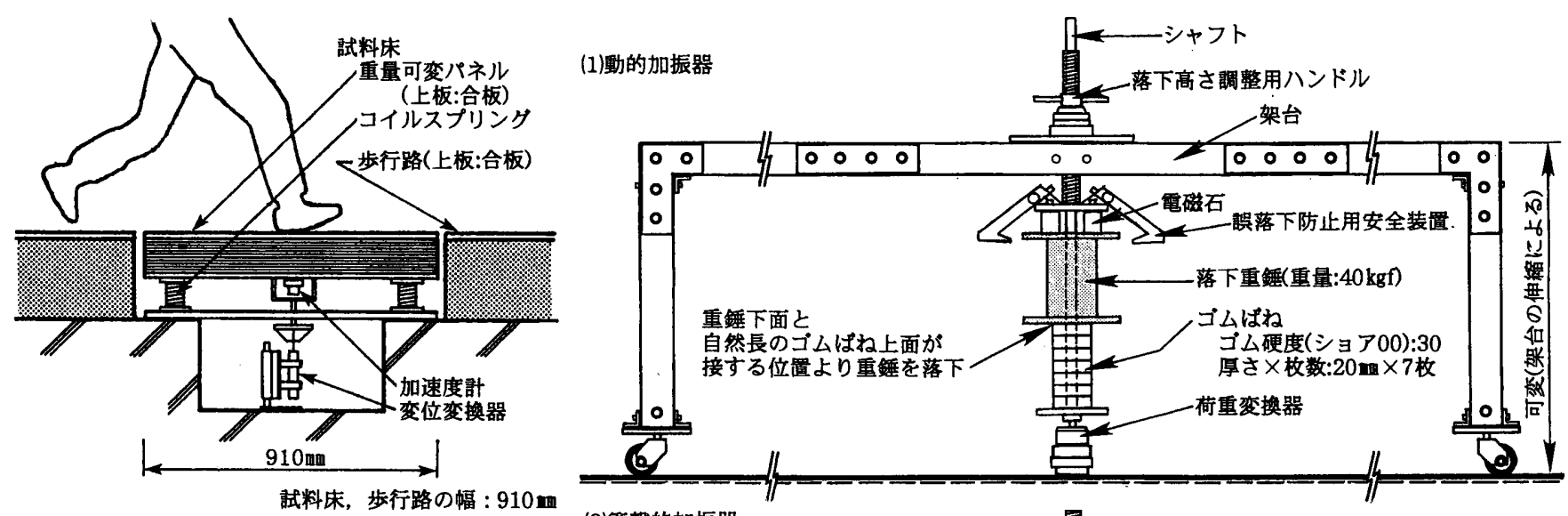

試料床の振動特性の範囲

重量可変パネルの重量W : 30.7 1073.5 kgf

固有振動数 $f: 5.18 \sim 32.6 \mathrm{~Hz}$

減哀定数 $h: 1.19 \sim 10.2 \%$

\section{図-2 試料床の概要 ${ }^{5), 6)}$}

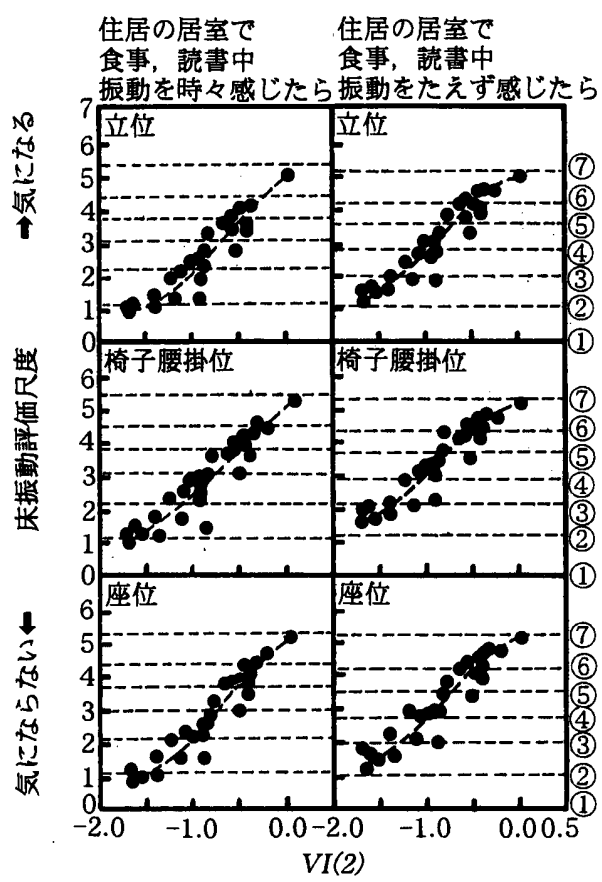

(7)非常に気になると思う(3)やや気になると思う

(5)かなり気になると思う年全く気にならないと思う

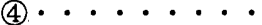

図一3 床振動の評価指標の例 (履物 : くつ下) $)^{4)}$
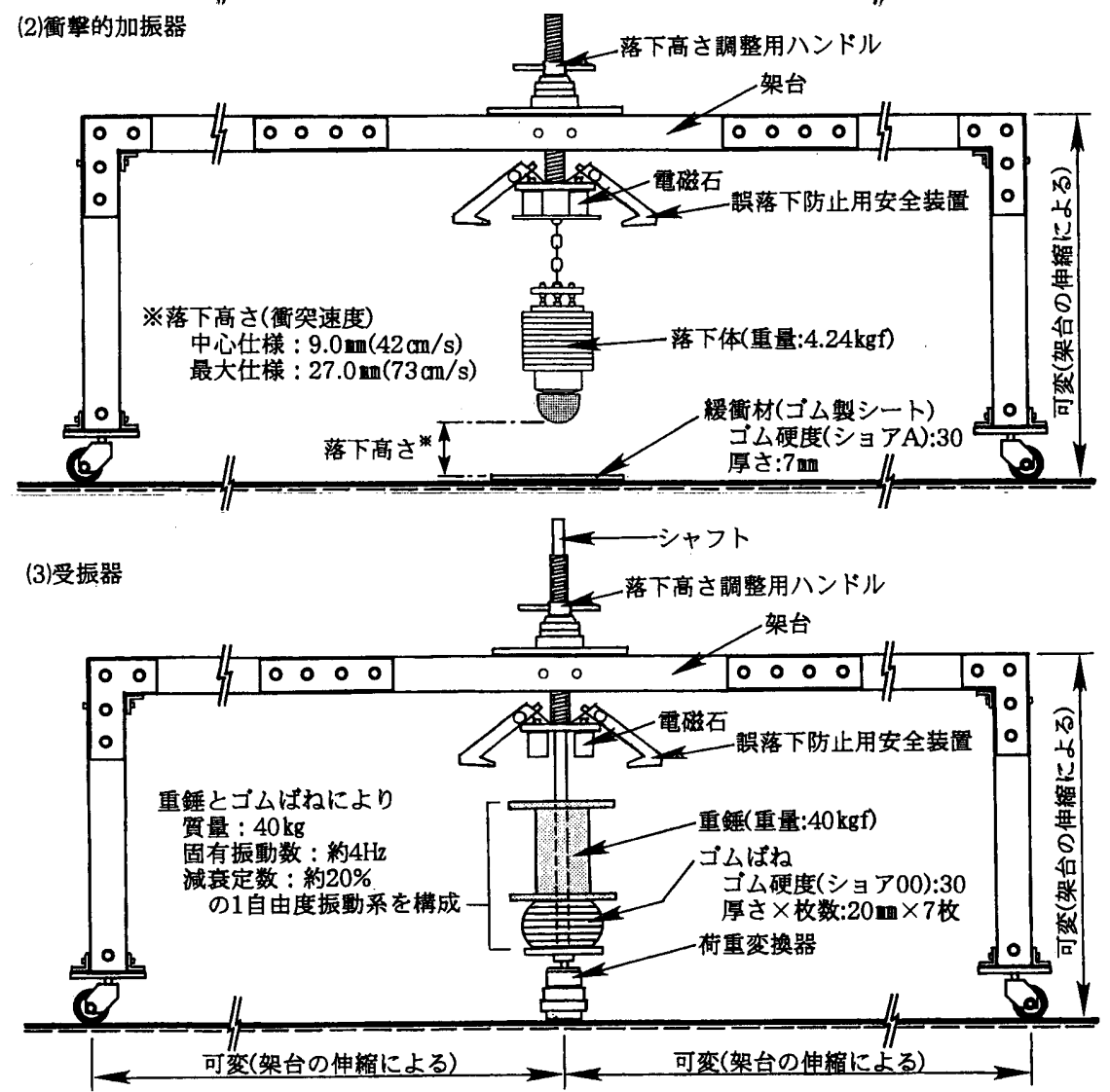

図-4 床振動測定装置の概要 ${ }^{5), 6)}$

\section{5. 本研究の研究方法}

本研究の研究方法は、以下の通りである。

1)種々の実在住宅から様々な木造, 軽量鉄骨造床を選定し、着地点, 居住点および測定点を適宜設定したうえで、数名の歩行者, 居住者 を用いて床振動を測定する。

2)1)と同一の床および着地点，居住点，測定点で、床振動測定装置を 用いて床振動を測定し、1)の結果と比較することにより、装置の実 在住宅床に対する適用性を確認する。

3)苦情発生の有無に関する何らかの資料が得られている多数の実在住 宅木造，軽量鉄骨造床を対象に、着地点，居住点および測定点を適 宜設定したうえで、床振動測定装置を用いて床振動を測定する。

4)3)の結果と各床における苦情発生の有無との関係を種々検討し、床 振動の測定条件および境界値を提示する。

\section{6. 床振動測定装置の実在住宅床に対する適用性の確認}

\section{1 対象床および着地点, 居住点, 測定点の概要}

歩行と床振動測定装置による床振動の测定, 比較に用いる対象床と して、実在する木造戸建住宅9棟(うち1棟は床板ALC造)，軽量鉄骨造 戸建住宅 9 棟， RC造集合住宅2棟(木造二重床および軽量鉄骨造二重床 各1棟)から各棟1室づつ、計20の居室の床を選定した。対象床には、

一般的な材料, 構法で床梁のスパンや各部材の寸法, 間隔, 接合方法 などを種々変化させたものや、試作的要素の強いものも含まれてい た。また対象床の仕上げは、いずれもフローリングであった。

各対象床上に、図一5に例示する要領で、歩行路，着地点，居住 点, 測定点を設定した。着地点は、対象床の中央付近で、かつ床架構 との関係から、合う床梁の中間かつ合う根太の中間など、比 較的振動が大きいと予想される位置に設定した。また一部の対象床で 


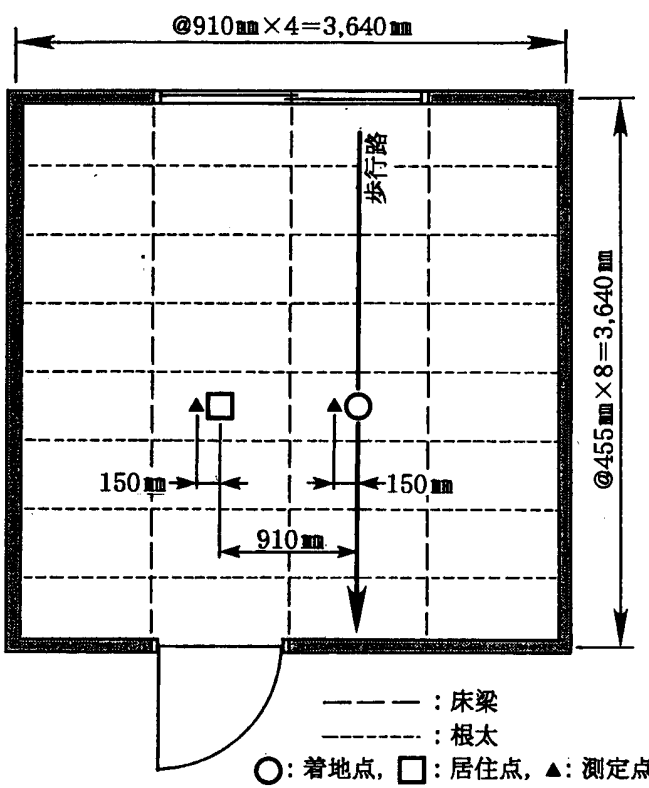

図-5 歩行路および着地点,居住点,測定点の設定例

は、床梁と根太の交差部上などにも着地点を設定した。さらに着地点 を含みかつ床梁または根太などと同じ方向に、歩行路を設定した。

一方、居住点は、床架構の間隔にあわせて、着地点から歩行路と直 交する方向に900〜 1000mmの位置に設定した。また測定点は、着地 点, 居住点の近傍 $(150 \mathrm{~mm}$ 離れた位置)に設定した。ただし約半数の対 象床では、実在住宅での測定上の制約から、居住点とその近傍の測定 点を省略した。

\section{2 歩行時の床振動の測定}

\subsection{1 測定要領}

歩行時の床振動を、以下の要領で測定した。

(1)歩行者, 居住者の属性

歩行者, 居住者は、ともに成人男子(年秢 : 22 45歳, 体重 : 49.0 〜97.4kgf)とした。これは、歩行者, 居住者の性による床振動の差は 小さい5),6)こと、および住宅で苦情の対象となる事例が多い成人の加 振力，人体の振動特性に基づいて床振動測定装置が開発されている5，6) ことによる。

(2)歩行者数および測定回数

実在住宅での制約の範囲内で出来る限り多くの歩行者数 $\times$ 測定回数 を確保することとし、結果的に $3 \sim 4$ 名 $\times 3 \sim 4$ 回、または 5 名 $\times 2 \sim 3$ 回 の測定を行った。また、居住点を設定した対象床では、待機中の歩行 者を順次居住者として用いた。

(3)歩行者の動作，居住者の姿勢

歩行者には、住宅内で通常行っている速さ，激しさで歩行するよう 教示し、歩幅，歩調などの規定は行わなかった。歩行者は測定前に、 着地点に足裏の中央が自然に着地するよう、歩行開始位置や歩数の調 整をかねた練習を十分行った。一方居住者の姿勢は、立位，椅子腰掛 位, 座位の範囲では床振動に大きく影響しない33,4)ことから、立位と した。居住者には、住宅内で通常想定される程度の足腰の弛緩状態 で、かつ重心が居住点とほぼ一致する位置に立つよう教示した。 (4)履物

歩行者の履物は、2.で述べた理由からくつ下とした。また居住者の

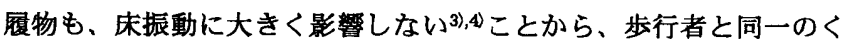
つ下とした。

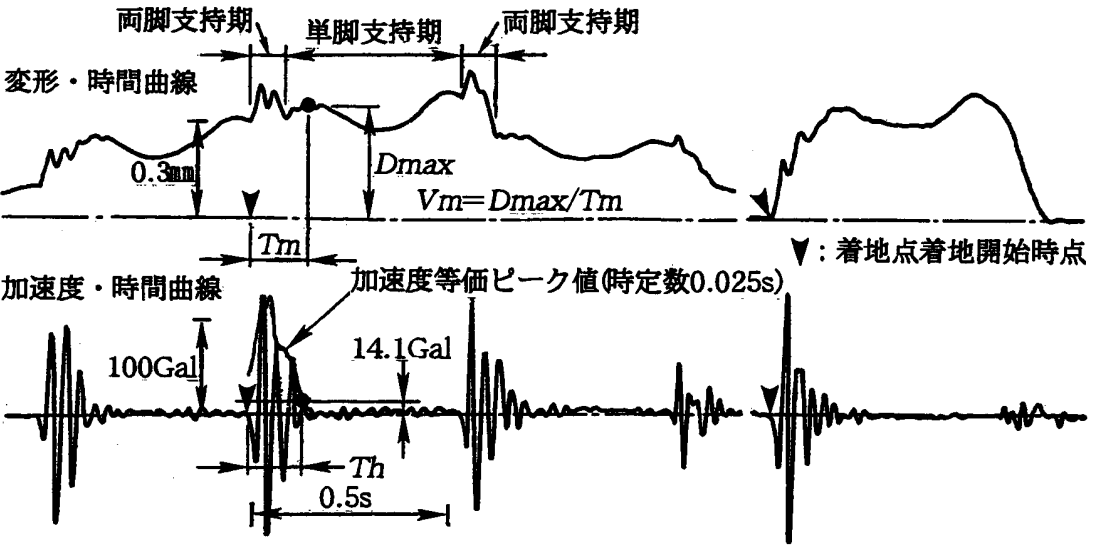

(1)数歩歩行した場合

(2)1歩のみの場合

図-6 歩行時の床振動の測定結果の例

\subsection{2 測定経過, 結果}

6.2.1で述べた要領で、歩行路上を数歩歩行した際の測定点の振動を 測定した。測定は、測定点に設置した加速度計と、下階の床もしくは 対象床周囲の壁体などほぼ不動とみなせる位置で支持した変位変換器 を用いて行った。なお、最初に測定した対象床では、参考のため、床 とは縁の切れた独立歩行路を周囲から掛け渡し、独立歩行路上から床 上の着地点に 1 歩のみ着地してまた独立歩行路上に歩き拔けた場合の 振動も測定した。

図一6に、測定の結果得られた変形・時間曲線，加速度・時間曲線 の典型例を示す。図は最初に测定した対象床での結果であり、歩行路 上を数歩歩行した場合の振動(図の(1))とあわせて、同一歩行者による 独立歩行路を用いた1歩のみの振動(図の(2))も比較して示した。

図の(1)に示した変形・時間曲線は、4.1で述ベたピーク $p_{2}, p_{3}$ など

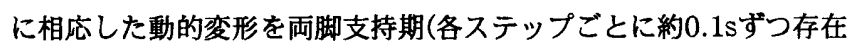
する両足が接地している時間)を重ねてつなぎ合わせた形状をしてお り、歩行者が測定点近傍の着地点に接近するにしたがって変形が增加 し、遠ざかるにしたがって減少する様子がうかがえる。一方、加速 度・時間曲線に示すように、床の固有振動数での減衰振動は、木造, 軽量鉄骨造床では一般に減衰が大きいため、多くの対象床で歩行ス テップの周期(約 $0.5 \mathrm{~s}$ )内に十分诚衰していた。なお、加速度の最大值 が数百Galを超える対象床がまれではなかったが、これらの値をその まま日本建築学会の居住性能評価指針・同解説9)などと照合すると、 明らかに著しく実状とかけ離れた評価となる。

また図の(1)と(2)の比較から、木造，軽量鉄骨造床では、最大値を含 む単脚支持期の変形 ・時間曲線、および着地時の加速度・時間曲線 は、前のステップの影響をほとんど受けないことが推察できる。

以上に例示した各対象床での测定結果から、振幅を $(60 \mathrm{kgf} /$ 歩行者 の体重)倍して基準化したうえで、図に示す要領で着地点着地時の $D \max , V m, T h$ 求め、VI(2)を算出した。

\section{3 床振動測定装置による床振動の測定}

6.2 と同一の対象床および着地点, 居住点, 測定点で、床振動測定 装置による測定を行った。着地点, 居住点に設置した装置の架台は、 対象床の周囲壁際など、䣓性が高く、対象床の振動性状にほとんど影 響しないとみなせる位置で支持した。測定は、测定点に設置した加速 度計を用いて行い、さらに一部の対象床では、ほぼ不動とみなせる位 置で支持した変位変換器も用いた。衝撃的加振器での測定は、中心仕 
様と最大仕様の2

種の仕様で行っ

た。なお測定回数

は、それぞれ3〜

5回程度とした。

图一7に、測定

の結果得られた変

形・時間曲線, 加

速度・時間曲線の

典型例を示す。図

の(1)は、動的加振

器による測定結果

の例として、不動

点で支持した变位

変換器で測定され

た変形・時間曲線

と、加速度計によ

る測定結果を二重積分して得られた変形・時 間曲線を比較して示したものである。加速度 計による測定結果は、計器の仕様上 $3 \mathrm{~Hz}$ 以下の 成分が除去されているため、変位変換器によ る直流 $(\mathrm{OHz})$ 成分まで含まれる測定結果とは異 なる曲線が得られている。VI(2)の算出には直 流成分まで含まれる曲線から得られるDmax, $V m$ 必要であるが、実在住宅では変位変換器 を不動点で支持するのが困難な場合が多い。

ここで、動的加振器の加振力には床の固有 振動数に近い成分は多くは含まれないことか ら、動的加振器による床応答の曲線の形状、 すなわち振動数特性には、床の特性は大きくは反映されないものと想 定できる。つまり、動的加振器による床応答の振動数特性は、3Hz以 上と以下の成分の関係も含め、床によりほとんど変化しないものと想 定できる。したがって、3Hz以下の成分が除去された曲線から得られ るDmax'，Vm'(図-7の(1)参照)を用いて、直流成分まで含まれる曲 線から得られるDmax, Vmを推定することが可能と考えられる。こ のことを確認する目的で、本研究では、振動特性の異なる種々の床を 用い、Dmax', $V m^{\prime}$ と $D \max , V m$ の関係を検討することとした。

図一8に、図一2に示す試料床を用い、振動特性を図に示す範囲で 種々変化させて求めたDmax', $V m^{\prime}$ と $D$ max, $V m$ の関係を示す。図 に示す通り、両者は非常によく対応しており、回帰直線から以下に示 す関係式を得ることができる。以上より本研究では、実在住宅では加 速度計を用いてDmax'，Vm'を測定し、結果を下式に代入して $D \max , V m$ を求めることとした。

$D \max =2.5 \cdot D \max$

$V m=2.9 \cdot V m^{\prime}$

一方図ー7の(2)は、衝撃的加振器による加速度・時間曲線の例を、 また(3)は、着地点に受振器を付加し床をハンマーで打撃して得られた 加速度・時間曲線の例を示したものである。図の(2)に示す通り、衝撃 的加振器による加速度・時間曲線には二度打ちの影響が含まれ、かつ 着地点に受振器が付加されていないため、Thを求めるためには、

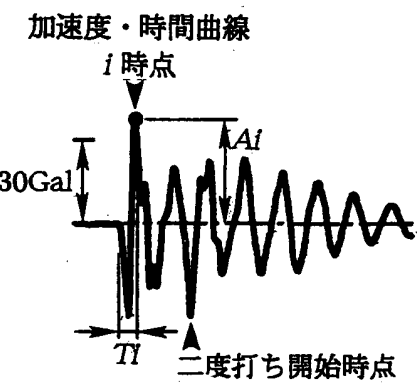

加速度・時間曲線

(2)惲撃的加振器による測定結果

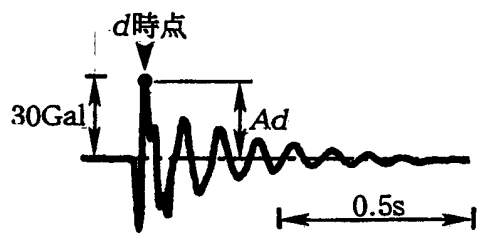

(3)受振器による測定結果

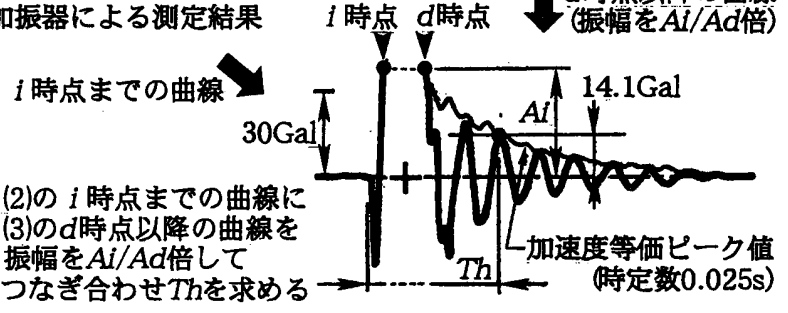

(4)Thの求め方の概要
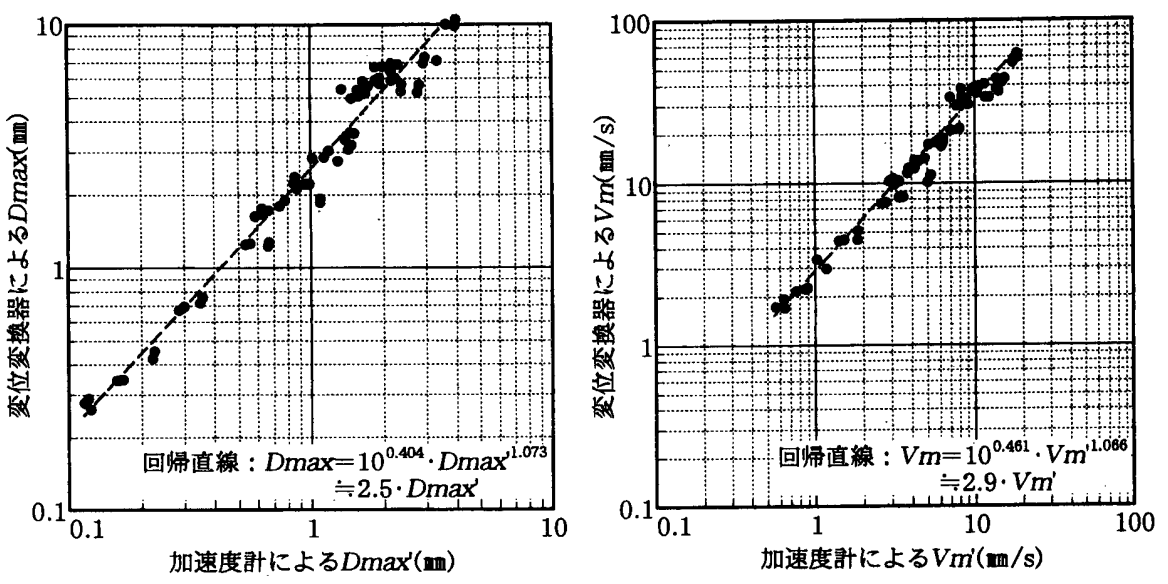

图-8 Dmax',VmとDmax,Vmの関係

Ai, Tiに受振器を用いて測定される床振動の減衰特性を何らかの方法 で組合せる必要がある。しかし実在住宅では、床構造の複雑さの影響 で、図ーリに示した単純な構造の試料床での測定結果と異なり、振幅 の半減時間Thalfを求めるのが困難な場合が少なくない。

ここで、图一7の(2)と(3)の曲線を比較すると、(2)の $i$ 時点近傍の曲 線の形状は、(3)のd時点近傍の曲線の形状と近似していることがわか る。これは、両者ともおもに床の固有振動数に近い成分での床応答で あり、加振方法の影㗽は衝撃の大きさの違いによる振幅の差のみに現 れることによるものである。よって本研究では、衝撃的加振器で再現 される振幅と、ハンマーでの打撃により再現される減衰特性を組合せ ることにより、二度打ちの影響が排除された振動减衰時間を求めるこ ととした。具体的には、衝撃的加振器による $i$ 時点(図一7の(2)参照) までの曲線に、受振器によるd時点(図の(3)参照)以降の曲線を振幅を $A i / A d$ 倍してつなぎ合わせる方法で、Thを求めることとした。図の (4)に、Thの求め方の概要を示す。

以上に述べた方法で、各対象床での測定結果からDmax, $V m, T h$ を求め、VI(2)を算出した。

\section{4 床振動測定装置の実在住宅床に対する通用性の確認}

6.2 と6.3で測定，算出した歩行と床振動測定装置によるDmax, Vm, Th，VI(2)の関係を、図-9に示す。Dmax，Vmについては、 歩行時の測定結果の平均と動的加振器による測定結果との関係を示 
す。またTh, VI(2)については、歩行 時のARよるばらつきが大きいことか ら、歩行時の測定結果の分布(最大, 最 小)と、衝撃的加振器(中心, 最大仕様) によるAiの測定結果に受振器, 動的加 振器による測定結果を組合せて算出し た結果との関係を示す。

上段の関係図から、動的加振器で歩 行時のDmax, $V m$ の平均を、おおむね 再現できていることがわかる。一方、 中，下段の関係図から：一部の対象床 で、歩行時の $T h, V I(2)$ の分布の中 心, 最大近傍が、衝撃的加振器(中心, 最大仕様) と受振器, 動的加振器による $T h, V I(2)$ よりさくなっていること がわかる。これは、実在住宅での測定 の際の歩行者数の制約によるものであ る。すなわち、測定に用いた歩行者の 中には、かかとの先端が着地した時点 の荷重のピーク $p_{1}$ (図ー1参照)が非常に 大きく、分布の上限近傍向の歩行者が数 名いたが、一部の対象床では、測定の 際これらの歩行者を用いることができ なかったため、Th，VI(2)の分布が小 さい方向にずれたことによるものであ る。しかし、他の対象床では両者は比 較的よく対応していることから、上述 の事情を考慮すると、衝撃的加振器(中 心, 最大仕様) と受振器, 動的加振器で 歩行時のTh, $V I(2)$ の分布の中心, 最 大近傍をおおむね再現できているとみ なしてかまわないものと考えられる。

以上より、面的広がりを有し曲げ変 形が支配的となる実在住宅床に対して も、床振動測定装置を歩行時の床振動 を再現する装置として適用できること が、確認できたといえる。

\section{7. 苦情発生の有無と床振動との関係の} 検討およひ測定条件, 境界值の提示

7.1 対象床および着地点, 居住点, 測定点の概要

苦情発生の有無に関する何らかの資料が得られている、木造戸建住 宅17棟(うち1棟は床板ALC造), 軽量鉄骨造戸建住宅13棟およびRC造 集合住宅 1 棟(軽量鉄骨造二重床)から、それぞれ31室，36室および1 室、計68の居室の床を対象床として選定した。対象床の仕上げは、い ずれもフローリングであった。

各対象床上に、図一10に例示する要領で、着地点, 居住点, 測定点 を設定した。着地点は、各対象床ごとに中央付近を中心に1〜3点設定 した。着地点の設定にあたっては、床架構などを参考に、対象床上で の最大に近い振動が得られると予想される位置を含むよう留意した。
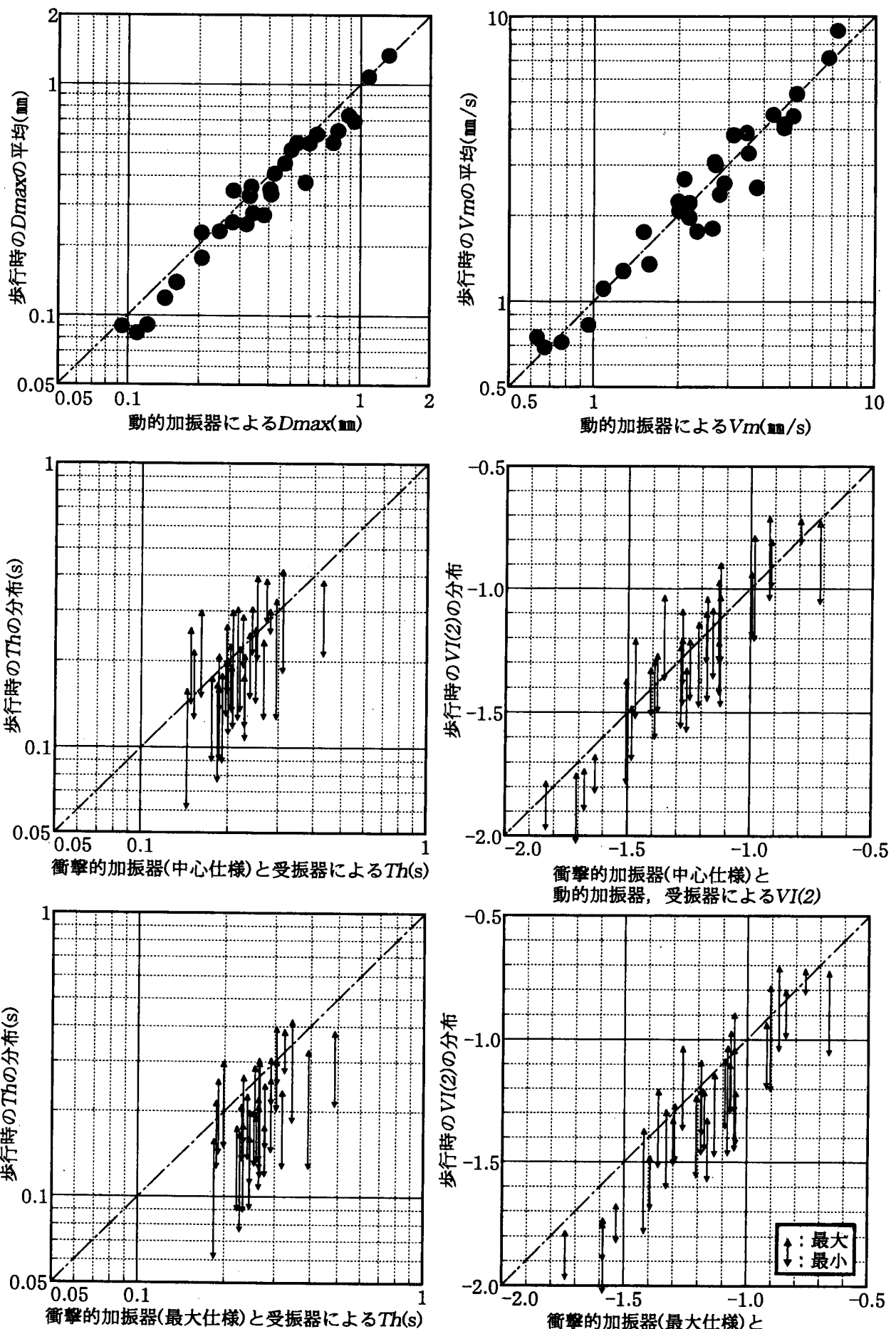

図-9＼cjkstart歩行と床振動測定装置による床振動の関係

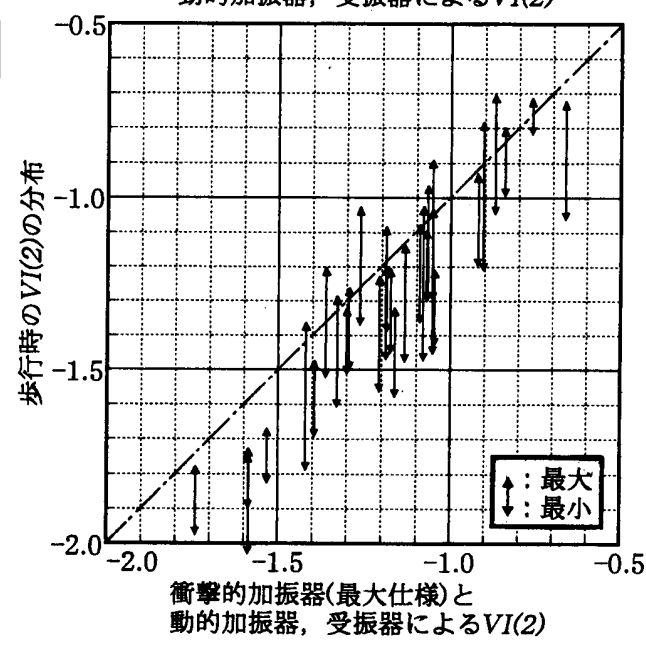

また居住点は、床架構の間隔にあわせて、着地点から900〜1000mm の位置に設定した。ただし後半に測定した約半数の対象床では、7.3 で述べる通り、それまでの測定結果から居住点の設定が必ずしも必要 でないことが明らかとなったため、実在住宅での測定上の制約を考慮 し居住点を省略した。

さらに測定点は、着地点と、着地点から床梁, 根太などの方向に 900 1000mmの位置に4点の、計5点を設定した。したがって居住点を 設定した対象床では、測定点のひとつと居住点が一致した。なお、対 象床の面積が小さく着地点から所定の距離がとれない場合には、該当す る測定点を省略した。 


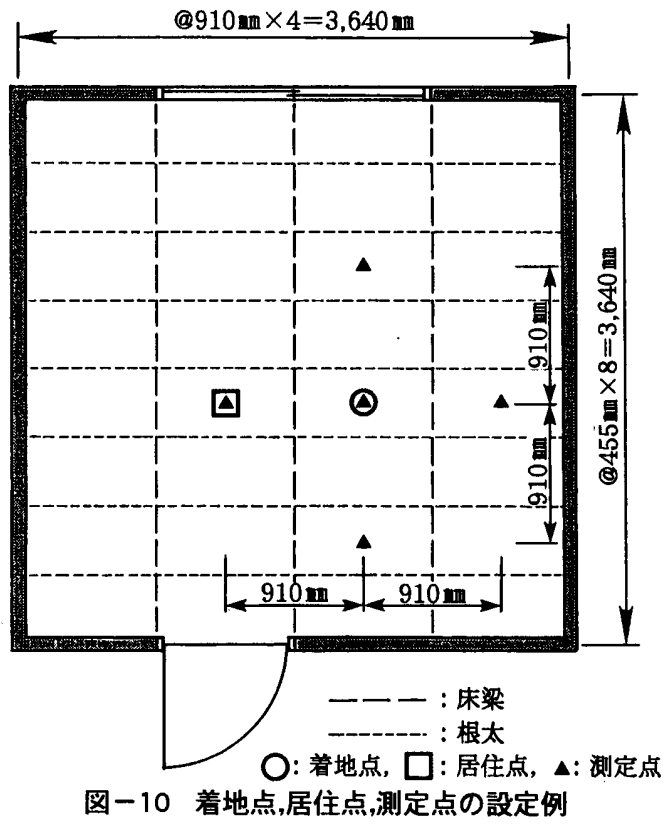

7.2 床振動測定装置による床振動の測定

7.1 で述べた対象床および着地点, 居住点, 測定点で、床振動測定 装置による測定を行った。測定は、1994年12月～2000年3月の間に 行った。着地点, 居住点に設置した装置の架台は、6.3で述べたと同 様の方法で支持した。測定は、測定点に設置した加速度計を用いて 行った。衝撃的加振器での測定は、中心仕様之最大仕様の 2 種の仕様 で行った。また居住点を設定した対象床では、居住点に受振器を付加 した場合の他に、参考として付加しない場合の測定も行った。なお測 定回数は、それぞれ3〜5回程度とした。

各測定点での測定結果から、6.3で述べた方法でDmax, Vm, Th を求め、VI(2)を算出した。

7.3 苦情発生の有無と床振動との関係の検討および測定条件, 境界 值の提示

7.2 の測定結果は長期間にわたる膨大なものであり、かつ実在住宅 での測定上避けられない様々な不確定要因が含まれるため、全測定結 果を対象とした定量的な検討を当初から行うのは困難と考えられる。 よって本研究では、はじめに全体的な傾向に関する定性的な検討を 行って実状に即した測定条件を提示し、つぎに提示した条件で測定, 算出されたVI(2)と苦情発生の有無との関係を定量的に検討し境界值 を提示することとした。

\subsection{1 床振動の測定条件の提示}

各対象床で測定されたVI(2)相互の関係、およびVI(2)と苦情発生の 有無との関係から、以下の事項が考察された。

(1)居住点を設定した対象床で、居住点に受振器を付加した場合の居住 点のVI(2)は、付加しない場合とほほ同等かもしくは若干小さくな る。これは、居住者の人体の振動特性を置換した受振器により、床 振動が若干吸収されることによるものと思われる。一方居住点以外 の測定点のVI(2)は、居住点に受振器を付加した場合としない場合 とでほとんど変化しない。

(2)居住点を設定した対象床の、居住点のVI(2)と苦情発生の有無との 関係に、明確な傾向はみられない。すなわち、7.1で設定した居住 点は、苦情発生の有無の観点から床を評価するうえで、必ずしも実 状に即しているとはいい難いことがうかがえる。一般に、任意の実

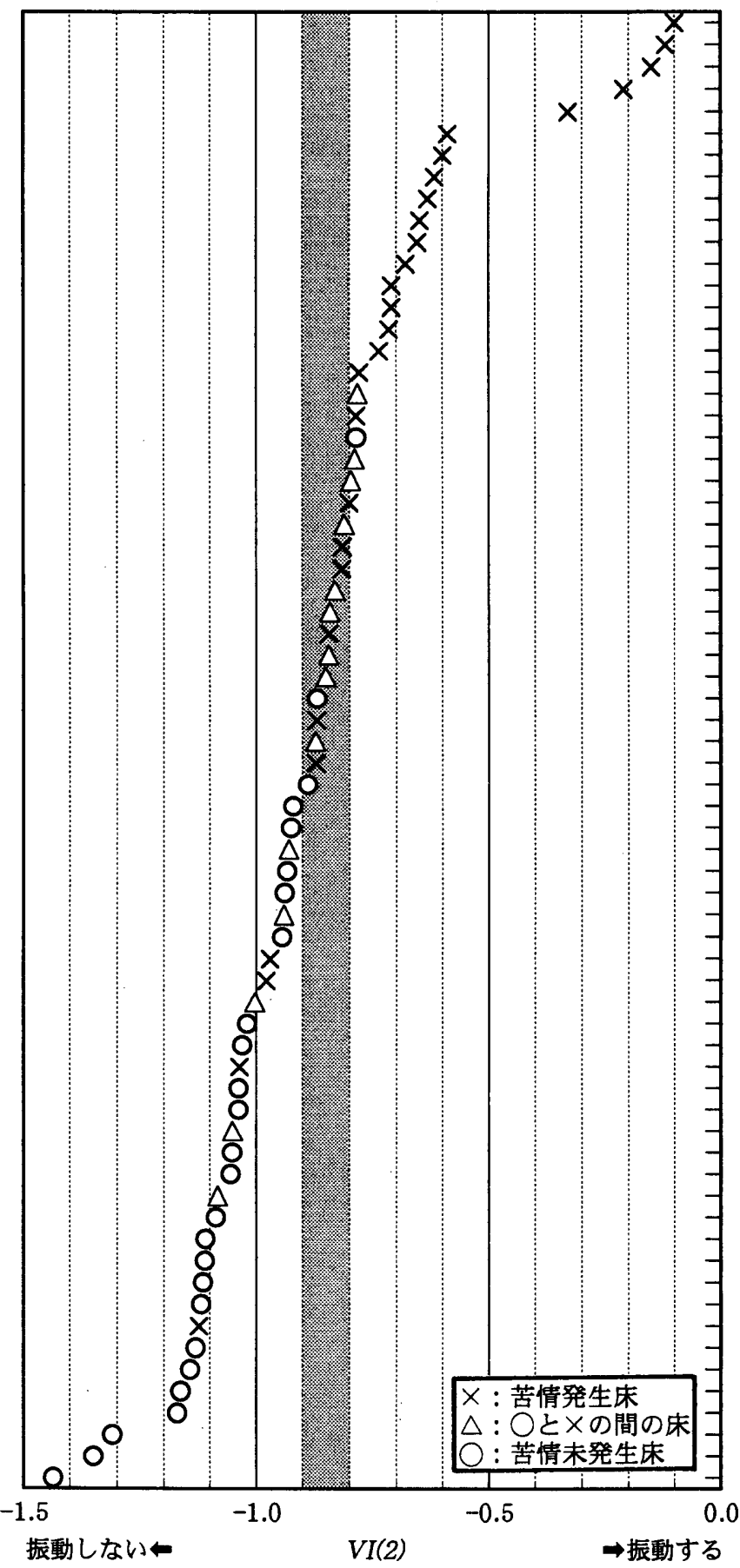

図-11 VI(2)之苦情発生の有無の関係

在住宅床を評価する場合、実状に即した居住点を特定するのは困難 な場合が多いと考えられる。

(3)各測定点でのVI(2)のうち、苦情発生の有無との関係に最も明確な 傾向がみられるのは、対象床上での最大に近い振動が得られると予 想される位置に着地点を設定した場合の、着地点でのVI(2)であ る。また、衝撃的加振器の中心仕様と最大仕様では、最大仕様での 測定結果から算出したVI(2)の方がより明確な傾向がみられる。す なわち、いずれの対象床でも、その対象床上で発生する最も大きな 振動が、苦情発生の有無と深く関係していることがうかがえる。こ の結果は、床振動は、日常生活において一度でも感じてしまうと、 以降居住者の意識が高まり苦清などにつながる可能性が高いこと を、示唆しているものと考えられる。 
以上の考察に加え、評価方法の実在住宅床へのより広い活用を図る うえで重要な測定の簡便さも考虑し、苦情発生の有無からみた床振動 の測定条件を以下の通り提示する。

・着地点 : 対象床上での最大に近い振動が得られると予想される 位置に設定する

・居住点 : 設定しない(着地点の振動にほとんど影響しないため)

・測定点 : 着地点の振動を測定する

・衝撃的加振器の仕様 : 最大仕様とする

\subsection{2 床振動の境界值の提示}

図ー11に、7.3.1で提示した条件で測定，算出されたVI(2)と苦情発 生の有無との関係を示す。図は、全対象床をVII(2)の順に縦軸に並べ、 苦情発生の有無を $\bigcirc 、 \triangle ， \times の$ 記号を用いて表示したものである。

図中の $\times$ は、実際に苦情が発生した床や、試作あるいは引き渡し前 の段階で開発，営業担当者が「おそらく苦情が発生する」と判断し何ら かの措置をとった床(以降あわせて“苦情発生床”と記す)を表す。また ○は、これまで苦情が発生していない床や、開発，営業担当者が「お そらく苦情は発生しないよ判断した床(以降あわせで苦情未発生床” と記す)を表す。さらに $\Delta$ は、○×の間の、苦情までには至らな かったものの居住者から「振動する」などの指摘があった床や、開発， 営業担当者が「ボーダーライン上」と判断した床を表す。

図より、網掛けで示す $-0.9<V I(2)<-0.8$ の床はおもに $\triangle$ 、それ より振動が大きいー $0.8<V I(2)$ の床はおもにメ、振動が小さいVI(2) <-0.9の床はおもにOとなっていることがわかる。ここで、VI(2)< -0.9でも一部の床が×あるいは $\triangle$ となっているが、これらの床での 苦情などの内容を詳細に検討した結果、歩行時に建具, 家具, 食器な ぞから発生するがたつき音や、床から発生する歩行音、あるいは観葉 植物, 照明器具, 視覚情報機器(テレビやパソコンのモニタなど)の摇 れなど、聴覚的, 視覚的要因が影響し苦情などにつながったことが考 察された。すなわち、聴覚的, 視賞的要因が関与する場合、より小さ なレベルの振動制御が要求されることが示唆された。

以上より、居住者が足部、皘部などの接床部位での触覚で感じる振

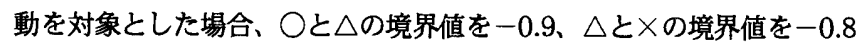
とみなしても、大きな間違いはないと思われる。よって本研究では、 苦情発生の有無からみた床振動の境界値を、以下の通り提示する。

・苦情が発生しない可能性が高い範同と

発生する可能性がある範囲の境界値 : $V I(2)=-0.9$

・苦情が発生する可能性がある範囲と

発生する可能性が高い範囲の境界値 : VI(2) $=-0.8$

ただし、上記境界值はあくまでも現段階までに蓄積された測定結果 から求めたものであり、今後さらなる測定結果の蓄積により、逐次妥 当性を検証してゆく必要があることを付け加える。

\section{8. おわりに}

本研究の結論をまとめると、以下の通りである。

1)様々な実在住宅木造, 軽量鉄骨造床を対象に、歩行と床振動測定装 置による床振動を測定, 比較した。その結果から、面的広がりを有 する実在住宅床に対しても、歩行時の床振動を再現する装置として 床振動測定装置を適用できることを確認した。

2)多数の実在住宅木造, 軽量鉄骨造床を対象に、苦情発生の有無と床 振動測定装置による床振動との関係を検討した。その結果から、苦
情発生の有無の観点から実在住宅床を評価する場合の実用的な床振 動の測定条件および境界値を、7.3で述べた通り提示した。

以上であるが、2)で提示した測定条件，境界値は、あくまでも苦情 発生の有無からみた実在住宅床の評価に床振動の評価方法を適用する 場合の例であり、他の場合には別途適用方法を検討する必要があるこ とを付け加える。なお今後は、実在住宅床で得られた境界値などと従 来の実験室での官能検查結果から得られた評価との関係や、より小さ なレベルの振動制御の必要性が示唆された聴覚的, 視覚的要因の影響 を含む床振動の評価方法などについて、研究を進める予定である。

\section{謝辞}

本研究のテーマ設定などにあたり種々御指導いただいた小野英哲先 生(東京工業大学教授・工博)に厚く御礼申し上げます。また、実在住宅 での床振動測定に御協力いただくとともに苦情の発生などに関する貴重 な資料を御提供いただいた住宅メ一力の関係各位に、謝意を表します。

\section{参考文献}

1)小野英哲，横山 裕 : 人間の動作により発生する床振動の振動感賞上の表示 方法に関する研究 一振動発生者と受振者が同じ場合一，日本建築学会㗚造 系論文報告集，第381号，pp.1 9，1987年11月

2)小野英哲，横山 裕 : 人間の動作により発生する床振動の居住性からみた評 価方法に関する研究 一振動発生者と受振者が同じ場合(動作した人間自身が 床振動を感じる場合)一，日本建築学会構造系論文報告集，第394号，pp.8〜 $16 ， 1988$ 年 12 月

3)横山 裕, 小野英哲：人間の動作により発生する床振動の振動感党上の表示 方法に関する研究 一振動発生者と受振者が異なる場合一, 日本建築学会構 造系論文報告集，第390号，pp.1～9，1988年8月

4)横山 裕, 小野英哲 : 振動発生者と受振者が異なる場合の床振動の評価方法の 提示人間の動作により発生する床振動の居住性からみた評価方法に関する研 究(第2 報)，日本建築学会構造系論文報告集，第418号，pp.1 8，1990年12月 5)横山 裕：歩行時に発生する床振動評価のための加振，受振装置に関する研 究 動的加振器, 受振器の設定および妥当性の梌㣙, 日本建築学会構造系論 文集，第466号，pp.21２9，1994年12月

6)横山 裕, 佐藤正幸 : 歩行時に発生する朱振動評価のための加振, 受振装置 に関する研究 衝擊的加振器の開発および振動減衰時間算出方法の妥当性の 確認，日本建筑学会構造系論文集，第476号，pp.21 30，1995年10月

7)横山 裕, 佐藤正幸 : 歩行時に発生する床振動評価のための加振, 受振装置 に関する研究 仕上げ材が施された床に対する加振，受振装置の適用方法の 設定，日本建策学会構造系論文集，第490号，pp.17２6，1996年12月

8)横山 裕: 歩行により発生する床振動の評価方法および住宅における評価 例， 日本建築学会大会学術講演梗概集， D - 1, pp.299 302，1999年9月 9) 日本建築学会 : 建築物の振動に関する居住性能評価指針・同解説，1991年4月 10)櫛田 裕 : 床の振動性状と最適睘境を考虑した設計法に関する研究 一床振 動評価基準に関する考察一，日本建築学会計画系論文報告集，第404号， pp.1 7，1989年10月

11)吉岡 丹，小野英哲，川村清志，茖ヶ原泰広 : 建築物の床のかたさおよびそ の評価方法に関する研究 その 2 . 㦿のかたさに関する心理学的尺度と物理 量の対応および床のかたさの訮価式・最適值の表示, 日本建築学会論文報告 集，第246号，pp.17〜24，1976年 8 月

(2000年11月 9 日原稿受理, 2001 年 3 月 21 日採用決定) 